\title{
Models of municipal management and personnel exchange with regions: are the implemented practices effective?
}

\author{
R. F. Turovsky ${ }^{1}$, A. P. Lyutikova ${ }^{1}$
}

${ }^{1}$ National Research University "Higher School of Economics”, 20 Myasnitskaya str., Moscow 101000, Russian Federation

DOI: $10.18255 / 2412-6519-2021-3-270-285$

Research Article

Full text in Russian

The reform of the municipal system carried out since 2010 has revealed changes in the models of power organization and the growing interest of the federal authorities in the formation of reliable managerial personnel at the local level. The analysis of biographies of heads of municipalities in 80 subjects of the Federation, conducted by the authors of the article, showed that the state authorities actively use the municipal level as a personnel reserve. The study systematizes data on the choice of municipalities of one of the three main management models - the model of an elected head, a single-headed model of a city manager and a two-headed model. The article shows that the process of recruiting the municipal elite in Russia since 2010 has been intertwined with the formation of the state bureaucracy and the deputy corps, and the regional and municipal elite have become inseparable from each other, which corresponds to the peculiarities of the functioning of regional political regimes in Russia, where there are no two independent levels of power. The paper uses statistical methods to confirm the expediency of switching to non-electoral models for determining municipal heads from the point of view of stabilizing the political regime.

The authors conclude that the reform of local self-government contributed to the formation of a unified system of public power in Russia before the constitutional reform of 2020, and the merging of the regional and municipal elite has a stabilizing political effect, playing an important role in strengthening the existing political regime.

Keywords: local self-government; local self-government reform; vertical of power; municipal heads; local elites; personnel policy

\section{INFORMATION ABOUT THE AUTHORS}

\author{
Turovsky, Rostislav F. $\mid$ E-mail: RTurovsky@hse.ru \\ (correspondence author) Doc. Sc. (Politics), Professor \\ \begin{tabular}{l|l} 
Lyutikova, Alina P. & $\begin{array}{l}\text { E-mail: ap.lyutikova@gmail.com } \\
\text { Student }\end{array}$
\end{tabular}
}

Funding: RFBR, project 20-011-31200

For citation: Turovsky R. F., Lyutikova A. P. Models of municipal management and personnel exchange with regions: are the implemented practices effective? // Social'nye i gumanitarnye znanija. 2021. Vol. 7, No 3. P. 270-285. (in Russ.)

(C) Turovsky R. F., Lyutikova A. P., 2021

This is an open access article under the CC BY license (https://creativecommons.org/licenses/by/4.0/) 


\title{
Модели муниципального управления и кадровый взаимообмен с регионами: эффективны ли реализуемые практики?
}

\author{
Р. Ф. Туровский ${ }^{1}$, А. П. Лютикова ${ }^{1}$
}

1Национальный исследовательский университет «Высшая школа экономики», Мясницкая, д. 20, Москва, 101000, Российская Федерация

DOI: $10.18255 / 2412-6519-2021-3-270-285$

УДК 321.02

Научная статья

Полный текст на русском языке

Проводимое с 2010 года реформирование муниципальной системы выявило смену моделей организации власти и возрастающую заинтересованность федеральных властей в формировании надежных управленческих кадров на местном уровне. Анализ биографий глав муниципалитетов в 80 субъектах Федерации, проведенный авторами статьи, показал, что государственная власть активно использует муниципальный уровень в качестве кадрового резерва. В исследовании систематизируются данные о выборе муниципалитетами одной из трех основных моделей управления: модели выборного главы, одноглавой модели сити-менеджера и двуглавой модели. В статье показано, что процесс рекрутирования муниципальной элиты в России с 2010 года переплетен с формированием государственной бюрократии и депутатского корпуса, региональная и муниципальная элита стали неотделимыми друг от друга, что соответствует особенностям функционирования региональных политических режимов в России, где не возникло двух самостоятельных уровней власти. В работе с помощью статистических методов подтверждается целесообразность перехода к невыборным моделям определения муниципальных глав с точки зрения стабилизации политического режима.

Авторами делается вывод о том, что реформирование местного самоуправления способствовало формированию в России единой системы публичной власти до проведения конституционного реформы 2020 года, а сращивание региональной и муниципальной элиты имеет стабилизирующий политический эффект, играя важную роль в укреплении существующего политического режима.

Ключевые слова: местное самоуправление; реформа местного самоуправления; вертикаль власти; муниципальные главы; локальные элиты; кадровая политика

\section{ИНФОРМАЦИЯ ОБ АВТОРАХ}

Туровский, Ростислав Феликсович (автор для корреспонденции)

E-mail: RTurovsky@hse.ru

Доктор политических наук, профессор департамента политики и управления

\begin{tabular}{l|l} 
Лютикова, Алина Павловна & $\begin{array}{l}\text { E-mail: ap.lyutikova@gmail.com } \\
\text { Студентка магистратуры }\end{array}$
\end{tabular}

Финансирование: РФФИ, проект № 20-011-31200 «Регионально-локальные отношения в условиях формирования единой системы публичной власти в современной России: теория и практика».

Для цитирования: Туровский Р. Ф., Лютикова А. П. Модели муниципального управления и кадровый взаимообмен с регионами: эффективны ли реализуемые практики? // Социальные и гуманитарные знания. 2021. Том 7, № 3. С. 270-285.

(C) Туровский Р. Ф., Лютикова А. П., 2021

Статья открытого доступа под лицензией СС BY (https://creativecommons.org/licenses/by/4.0/) 
Проблематика организации местного самоуправления и эффективности его устройства давно находится в фокусе внимания исследователей. На протяжении последних двух десятилетий в субъектах Федерации происходит активное реформирование муниципальной системы, в частности, в 2010-е годы наблюдался рост числа случаев смены моделей организации власти на локальном уровне. Кроме того, из-за институциональных особенностей действующего политического режима, среди которых важны ориентированность на предсказуемые результаты выборов и иерархизация территориальной системы, все больше возрастает заинтересованность федеральных властей в формировании надежных управленческих кадров на местах. Закономерным становится вопрос о том, насколько целесообразными и эффективными являются реализуемые реформы местного самоуправления и каковы реальные политические основания для их проведения.

Создание современной системы местного самоуправления в России происходило в несколько этапов. Основы были заложены еще в начале 1990-х гг., в период, характеризующийся стихийностью процесса формирования демократического самоуправления на фоне распада СССР и стремлением организовать новую систему по подобию западных федераций. С точки зрения классической теории федерализма, каждый уровень власти, не исключая местный, обладает собственными источниками доходов и имеет возможность, например, самостоятельно определять направления реализации расходной политики [1]. Так, принятый в 1995 г. закон «Об общих принципах организации местного самоуправления в Российской Федерации» становится основой для формирования нормативно-правовой базы о местном самоуправлении на федеральном уровне, на уровне субъектов Федерации и, собственно, на муниципальном уровне ${ }^{1}$. Особенностью данного этапа является преобладание прямых выборов глав муниципальных образований, что соответствует и концепции федерализма, предполагающей децентрализацию процесса принятия политических решений и распределение власти между ее разными уровнями.

В начале 2000-х гг. в рамках общефедерального курса на рецентрализацию политической системы был запущен очередной процесс административного реформирования. Ключевым моментом стало принятие в 2003 г. нового закона «Об общих принципах организации местного самоуправления в Российской Федерации», имплементация которого в первой его версии происходила вплоть до 2009-2010 гг. ${ }^{2}$ Основное назначение реформы заключалось в разграничении полномочий между федеральным, региональным и муниципальным уровнями власти, упорядочивании функций и приведении ресурсов МСУ в соответствие с объемом возлагаемых на него обязательств [2]. Однако фактически с помощью данной реформы федеральные власти стремились сформировать условия для обеспечения контроля политического процесса на всех уровнях системы.

Исследователи авторитарных режимов отмечают, что выборы на субнациональном уровне, в частности на локальном, могут способствовать консолидации авторитарного режима [3]. Например, с 2001 по 2012 гг. выборы мэров городов чаще

\footnotetext{
${ }^{1}$ Федеральный закон от 28 августа 1995 г. № 154-Ф3 «Об общих принципах организации местного самоуправления в Российской Федерации». URL: http://www.kremlin.ru/acts/bank/8267/print (дата обращения: 25.02.2020). ${ }^{2}$ Федеральный закон от 6 октября 2003 г. № 131-Ф3 «Об общих принципах организации местного самоуправления в Российской Федерации». URL: http://www.kremlin.ru/acts/bank/20035 (дата обращения: 25.02.2020).
} 
всего обеспечивали лояльность элит и позволяли федеральному центру задействовать их ресурсы, поскольку региональные и локальные режимы оказываются кооптированными во властную вертикаль [4]. Формирование иерархии не стоит рассматривать исключительно с точки зрения контроля федерального центра или же губернаторов за ситуацией на низовых уровнях. Для акторов локального уровня участие в данном процессе также выгодно в силу наличия доступа к благам, которые в ином случае оказываются недоступными. Важно, что интересы нижестоящих агентов не должны идти вразрез с общим политическим курсом. Так, в частности, из-за распространенности в прошлом конфликтов по линии «губернатор - мэр» к началу 2010-х гг. возникает запрос, во-первых, на пересмотр моделей управления МСУ и способов отбора глав муниципальных образований и, во-вторых, на обращение к кадровой политике, способствующей кооптации местных акторов в рамках консолидированного режима власти.

С 2014 г. вносятся многочисленные изменения в действующее законодательство, регулирующее устройство МСУ1. В частности, региональные органы государственной власти получают право единолично определять порядок формирования органов местного самоуправления на территории субъекта. Процесс трансформации муниципальной системы в начале 2010-х гг. демонстрирует появление двух ключевых развилок. Заметим, что смена модели предполагает не только изменение способа избрания главы муниципального образования, но и формирование новой институциональной модели управления, пересмотр устройства локальных режимов. Первая развилка заключается в необходимости выбора между системой прямых выборов главы муниципалитета и отказом от подобной практики. Вторая подразумевает установление единоличной модели муниципального управления или же формирование двоецентрия муниципальной власти. Таким образом, для России 2010-х гг. становится характерным наличие трех основных моделей МСУ - модели прямых выборов мэра, предполагающей единоначалие муниципальной системы, одноглавой модели сити-менеджера (главы администрации), а также двуглавой модели (в лице главы представительного органа, официально руководящего муниципалитетом, и главы администрации).

Распространенная в начале 2010-х гг. на замену прямым выборам практика формирования двуглавой модели подразумевает, что руководство муниципалитета представлено как главой муниципалитета, так и главой администрации (сити-менеджером). При двуглавой модели власть главы муниципального образования обычно является номинальной [5]. По инициативе федерального центра муниципалитеты стали менять уставы, в которых отражалась ориентация на отмену прямых выборов. Вместе с тем начинает развиваться институт сити-менеджеров, работающих по контракту с советами муниципалитетов.

Согласно первоначальным положениям муниципальной реформы, треть членов конкурсных комиссий, отвечающих за отбор кандидатур сити-менеджеров, должна была определяться региональными администрациями. В дальнейшем про-

\footnotetext{
${ }^{1}$ Федеральный закон от 27 мая 2014 г. № 136-Ф3 «О внесении изменений в статью 26.3 Федерального закона «Об общих принципах организации законодательных (представительных) и исполнительных органов государственной власти субъектов Российской Федерации» и Федеральный закон «Об общих принципах организации местного самоуправления в Российской Федерации». URL: http://www.kremlin.ru/acts/bank/38501 (дата обращения: 27.02.2020).
} 
цент представителей региональных администраций был увеличен до 50, что значительно усилило региональный контроль. Соответственно, формирование конкурсной комиссии попадает в ведение губернатора, а значит, справедливым будет заключить, что реформа МСУ привела к укреплению вертикали власти. Такая система виделась как более эффективный способ найма квалифицированного управленческого персонала, а также налаживания отношений между местной администрацией и исполнительной властью региона. Позитивной стороной подобных изменений среди прочих аспектов, таких как оптимизация финансовых расходов, обычно считается рост эффективности управления МСУ в силу повышения уровня профессионализма глав.

В свою очередь, возникшая позднее в связи с запросом на укрепление вертикали власти со стороны губернаторов одноглавая модель сити-менеджера подразумевает, что глава администрации назначается по конкурсу и является главой муниципального образования. При этом спикер представительного органа не является главой муниципального образования. Представляется, что именно эта модель больше всего отвечает интересам региональных властей, так как из ее наличия следует концентрация муниципальной власти в руках сити-менеджера, что закрепляет статус-кво с доминированием исполнительно-распорядительного органа власти в условиях снижения контроля со стороны муниципальной ассамблеи (поскольку ее председатель больше не глава муниципалитета) и роста контроля со стороны губернатора (с его преобладающим влиянием на состав конкурсной комиссии). Так решается задача управленческой оптимизации вертикали.

Таким образом, для российского квазифедерализма становится свойственным иерархический характер организации политического процесса в логике принципал-агентских отношений, при котором нижние уровни попадают в зависимость от вышестоящих акторов [6]. Ранее нами уже проводилось рассмотрение иерархической системы взаимоотношений между разными уровнями власти в России в рамках теории принципал-агентских отношений, и данный подход продемонстрировал свою состоятельность [7; 8]. Одной из задач выстраиваемой системы является обеспечение агентами на местах удовлетворительных для принципала электоральных результатов, но при этом отношения между принципалами и их агентами в целом характеризуются расхождением интересов и тенденцией со стороны агента уклоняться от ответственности, установленной принципалом.

В силу территориальных масштабов России осуществление контроля требует институционального закрепления. Как принятие местным руководством решения об отмене прямых выборов глав МСУ, так и реализация кадрового взаимообмена между уровнями власти являются закономерными инструментами для обеспечения контроля деятельности местных органов власти, которые, в свою очередь, находясь на самом низовом уровне, напрямую взаимодействуют с населением, а значит, и потенциальным электоратом. В частности, в соответствии с теорией патрон-клиентских отношений, доминирующая ранее модель прямых выборов, при которой главы муниципалитетов избираются населением, становится неудобной для обеспечения контроля над ресурсами и регулирования локальной политики, и предпочтение отдается моделям, при которых главы муниципалитетов тем или иным способом назначаются. Возможной является и «компромиссная» модель сити-менеджера, при которой глава муниципального образования избирается населением, но является спикером представительного органа. Подобная модель позволяла региональной 
элите влиять на администрации муниципалитетов, как например, в случае Екатеринбурга в 2013 г. Более надежные патрон-клиентские сети тем не менее складываются при классической модели сити-менеджера, которая не предполагает прямых выборов глав МСУ. Закономерным представляется и сценарий, при котором на пост сити-менеджера назначается актор, связанный с губернаторской клиентелой.

Несмотря на заключения ряда исследователей о том, что российская муниципальная система оказалась встроенной в единую властную вертикаль, наблюдение результатов реформы все еще представляется актуальной задачей. Научное сообщество неоднократно обращалось к анализу реорганизованной муниципальной системы, в частности, к подробному описанию данной реформы МСУ и наблюдению за динамикой установления вариативных моделей управления муниципальными образования $[9 ; 10 ; 11]$, однако открытым остается вопрос о том, какие эффекты имели рассматриваемые преобразования на действующую политическую систему. Что примечательно, эмпирического подтверждения эффективности реформы с точки зрения поддержания действующего политического режима не было. В качестве исключения можно указать на близкую по проблематике работу А. Трудолюбова и М. Экбы, которые с опорой на статистический анализ установили факт бесполезности реформы МСУ с точки зрения вопроса территориального деления субъектов [12]. Кроме того, эти авторы отметили отсутствие значимой динамики в исследованиях данной реформы. Таким образом, настоящая работа является новой попыткой поиска объективных оснований для утверждений о том, что реализуемая центром реформа МСУ привела к ожидаемым результатам с точки зрения сближения двух уровней власти и усиления иерархического политического контроля.

Ключевой вопрос данного исследования состоит в следующем: какой эффект оказывает консолидация публичной власти в регионах (через кадровый взаимообмен и через укрепление и упрощение управленческой вертикали) на электоральную эффективность всей действующей власти. В силу того, что политический режим в России принято рассматривать через призму критической важности выборов для сохранения политической стабильности, для ответа на поставленный вопрос мы обратимся к наблюдению за поддержкой президента страны населением с акцентом на то, как влияет реформирование муниципального уровня власти на способность системы обеспечивать ожидаемые центром результаты. Иными словами, нам необходимо установить, насколько результативны меры по иерархизации политической системы и, в частности, инкорпорированию МСУ в эту систему.

Цель данного исследования состоит в необходимости проанализировать распространенность различных практик управления муниципалитетами на территории регионов России с определением их влияния на устойчивость действующего политического режима, а также обозначить связанные с этим тенденции в кадровой политике муниципального уровня. Анализ кадровой политики на муниципальном уровне и процессов рекрутирования муниципальных акторов, наблюдение за хронологией реформирования системы управления муниципальными районами и городскими округами на территориях разных субъектов Федерации могут позволить сделать заключения о том, насколько эффективной оказывается политика федеральных властей по реформированию МСУ.

Эмпирическая часть исследования состоит из нескольких разделов. Во-первых, проводится биографический анализ, целью которого является поиск основа- 
ний для объективных заключений о процессе сближения регионального и муниципального уровней власти через наблюдение переходов акторов между уровнями. На основе данного анализа мы намереваемся продемонстрировать наиболее характерные случаи обмена кадрами на примере нескольких регионов. Биографический анализ предусматривает изучение корпуса муниципальных руководителей (глав муниципальных образований и/или глав администраций, в зависимости от модели местного самоуправления) с точки зрения наличия определенных биографических характеристик, значимых для данного исследования: опыт работы в органах государственной власти (федеральных и региональных органах), опыт работы в органах муниципальной власти, в т. ч. представительной (законодательной) власти регионального и муниципального уровня, органах региональной исполнительной власти, муниципальных администрациях; опыт партийной деятельности и партийная принадлежность.

Во-вторых, производится анализ сменяемости моделей МСУ в разных субъектах страны. Актуальность наших подсчетов основывается на том, что если ранее экспертами и делались заключения о тенденциях развития данных процессов, то они основывались преимущественно на данных о региональных центрах, то есть выборка ограничивалась примерно 80 наблюдениями. В данной работе проводится изучение более широкой совокупности муниципальных образований с последующими заключениями о том, в какие годы происходила трансформация системы в разных субъектах и какая доминирующая модель устанавливалась в том или ином регионе. Осуществляется анализ нормативно-правовых актов муниципальных образований и региональных СМИ на предмет того, в какой период происходила смена модели МСУ, какая модель имела место до перехода и после.

В-третьих, мы осуществляем построение простой линейной регрессии для проверки влияния смены моделей на политическую эффективность действующей власти. Иными словами, мы стараемся определить, влияет ли консолидация двух уровней публичной власти в регионах на поддержку действующего президента.

Наше исследование охватывает период с 2005 по 2020 гг. Особенностью данного периода является то, что в эти годы происходит, продолжаясь и по сей день, имплементация реформы МСУ 2003 г. Выбранные хронологические рамки позволяют делать заключения о том, с какой интенсивностью происходила консолидация политической системы в разных субъектах Федерации.

Анализ кадровой политики, основанный на рассмотрении биографий более 2000 глав муниципалитетов в России, продемонстрировал наличие схожей траектории профессионального продвижения муниципальных глав, которую можно описать, как кадровый лифт. Наиболее распространенной практикой является переход муниципального руководства в представительные органы власти вышестоящего, т. е. регионального и федерального уровня. Закономерно и то, что большинство акторов являются аффилированными с партийными организациями, преимущественно с «Единой Россией». В качестве примера можно привести Б. Хохрякова главу города и главу администрации Нижневартовска с 2003 по 2011 гг. До момента вступления на пост главы Нижневартовска он возглавлял одноименный район в Ханты-Мансийском АО, а после стал председателем Думы региона. В. Волончунас, глава Ярославля с 1995 по 2012 г., после отставки стал депутатом областной Думы. 
Наибольший интерес представляют случаи, когда мэры городов становятся главами регионов. Можно отметить А. Козлова, который стал губернатором Амурской области, до этого возглавляя администрацию Благовещенска. Начав политическую карьеру на посту заместителя министра строительства, архитектуры и ЖКХ и продолжив ее в качестве министра в Амурской области, А. Козлов после отставки с губернаторского поста переходит на федеральный уровень и занимает позицию министра по развитию Дальнего Востока и Арктики, а затем - главы Минприроды. Показательна также биография Д. Азарова, занимавшего в 2010-2014 гг. пост главы городского округа Самары. С 2018 г. Д. Азаров становится губернатором Самарской области, однако в данном случае показательно не только формирование тесной связи между муниципальным и региональными уровнями. В 2014-2017 гг. этот политик был членом Совета Федерации, успев, таким образом, поработать и на федеральном уровне.

В качестве ярких примеров также стоит упомянуть А. Кокорина, Д. Кобылкина и С. Носова. А. Кокорин, ранее глава администрации г. Шадринска Курганской области, впоследствии занимал пост губернатора данного региона. Аналогичным образом Д. Кобылкин, являясь экс-главой Пуровского района Ямало-Ненецкого АО, переходит на позицию главы региона, а затем - министра природных ресурсов и экологии РФ. А С. Носов, мэр Нижнего Тагила, становится губернатором уже совсем другого региона - Магаданской области. Есть и другие случаи, когда мэры, становясь губернаторами, покидали свои субъекты Федерации. Например, А. Травников в 2012 г. стал мэром Череповца, а в 2016 г. возглавил администрацию Вологды. После этого он назначается губернатором Новосибирской области. Примечательно, что политическая карьера обозначенных политиков изначально напрямую не связана с работой в региональных центрах. Справедливым будет заключить, что руководство муниципалитетом вне региональных столиц также может восприниматься в качестве источника пополнения кадров для управления субъектами Федерации, несмотря на, казалось бы, более низкий статус этих муниципальных образований.

Конечно, не все муниципальные главы достигают позиции главы исполнительной власти субъекта Федерации, но тем не менее большой ряд политиков, возглавлявших ранее муниципальные администрации, впоследствии был инкорпорирован в региональные органы власти. Например, Ю. Маков, глава городского округа Волгореченск, и А.Резунов, глава администрации Красногорского района, были назначены заместителями губернаторов Костромской и Брянской областей соответственно. С. Бидонько, глава администрации Карпинска, также имел схожий путь продвижения по службе в Свердловской области.

Еще один важный процесс - это обратные перетоки кадров с регионального на муниципальный уровень. Например, П. Березовский, ставший в 2016 г. мэром Шимановска, до этого являлся советником губернатора Амурской области. Еще один интересный пример - Е. Никора, глава администрации Мурманска. Его биография примечательна тем, что, являясь председателем Мурманской областной думы в 2008-2011 гг., а затем заместителем губернатора данного региона в 2016-2019 гг., он после этого возглавляет ключевую муниципальную администрацию в регионе, таким образом становясь связующим звеном между разными уровнями политической системы.

Как нами уже отмечалось, консолидация регионального и местного уровней власти не только основывается на кадровом взаимообмене, но и регламентируется 
институциональными ограничениями. В случае анализа изменения моделей формирования местных органов власти стоит отметить исследование А. Трудолюбова, в котором автор делает вывод о наличии тенденции в пользу отказа от модели прямых выборов на примере поселений в регионах ЦФО [13]. В рамках нашего исследования мы расширяем географические рамки и рассматриваем 2058 кейсов на предмет изменения или же сохранения в них системы управления МСУ в 80 субъектах РФ. Исключение составили города федерального значения Москва, Санкт-Петербург и Севастополь, а также Московская и Ленинградская области, т. е. субъекты без областных центров. В 1471 случае, то есть в подавляющем большинстве, наблюдалась смена управленческих моделей в муниципальном образовании, в остальных - сохранение ранее установленной системы формирования органов власти. Важно отметить, что часть рассмотренных кейсов отражает последовательный «двойной» переход. Так, например, в Барнауле и Нижнем Новгороде в 2010 г. произошел переход от модели выборного главы к двуглавой модели, а в 2018 г. она сменилась на одноглавую модель сити-менеджера. Аналогичная ситуация последовательно наблюдалась в 2010 и 2014 гг. в Великом Новгороде, в 2010 и 2015 гг. в Оренбурге и Челябинске, в 2011 и 2016 гг. в Петропавловске-Камчатском и Ханты-Мансийске, в 2011 и 2018 гг. в Ульяновске, в 2014 и 2015 гг. в Самаре. Уже при первом рассмотрении становится очевидным, что смена моделей на территории Российской Федерации не была синхронной.

Примечательно, что выборка кейсов за период начала реформы с 2005 по 2009 гг. включает только 31 случай смены моделей. Например, за это время произошел переход от прямых выборов глав к двуглавой модели в 6 муниципалитетах Карачаево-Черкесской республики, а также в 14 муниципалитетах Алтайского края. Единичные случаи наблюдались в республиках Дагестан, Карелия и Чувашия, Красноярском крае, Курганской, Самарской, Нижегородской, Тамбовской и Тверской областях. Во всех указанных случаях смена моделей происходила в муниципальных районах и также в трех городах - Новоалтайске, Сызрани, Минусинске, но процесс смены моделей МСУ в интересах губернаторов в более крупных муниципальных образованиях начался с заметным запозданием.

В то же время основной массив собранных нами данных содержит информацию по кейсам гораздо более активной смены системы муниципального управления между 2010 и 2020 гг., что совпадает и с интенсификацией кадрового обмена между региональным и местным уровнями власти. Стоит отметить общую тенденцию сменяемости моделей с переходом от модели выборного главы муниципалитета к двуглавой модели, а после (но еще далеко не везде) - к одноглавой модели сити-менеджера. Однако в разных субъектах Федерации процесс смены моделей тем не менее имеет свои особенности. Для установления того, как он протекал в отдельных муниципалитетах, нами был проведен анализ нормативно-правовых актов муниципальных районов и городских округов, а также изучались данные о проведении муниципальных избирательных кампаний. Нами фиксировались, во-первых, модель МСУ, действующая на конец 2020 г., и, во-вторых, модель (или модели в случае повторного «перехода»), которая действовала ранее, при обнаружении факта смены процедуры формирования органов власти муниципалитета. Соответствующие изменения, как правило, отражаются в виде поправок к документам и отмечаются экспертами в региональных СМИ. На основе проведенного анализа релевантным представляется выделение несколько тенденций: 


\section{I. Сохранение модели выборного главы и отсутствие смены модели}

Напомним, что модель прямых выборов глав предполагает избрание главы муниципалитета на прямых выборах, по итогам которых избранный кандидат становится главой администрации. Подобная практика была распространенной в России до 2009-2010 гг., однако, как показал наш анализ, даже после очередного реформирования системы в 2014г. и массового перехода значительного числа муниципальных образований к иным процедурам определения своих глав модель прямых выборов все же сохранилась в ряде субъектов. Например, преобладание прямых выборов глав наблюдается в муниципалитетах Якутии, Чукотского АО и Псковской области. Примечательно, что в Псковской области только в двух основных городах - Пскове и Великих Луках - действует более удобная для губернатора двуглавая модель сити-менеджера. На обозначенных территориях в период с 2005 по 2020 гг. факты смены моделей случаются в единичных случаях. Кроме того, можно отметить Архангельскую, Амурскую, Вологодскую и Костромскую области, в которых около трети муниципалитетов первого уровня сохранили практику прямых выборов.

\section{II. Сохранение двуглавой модели сити-менеджера}

Процесс смены выборной модели на двуглавую между 2005 и 2020 гг. не был зафиксирован по причине отсутствия документального подтверждения смены модели в уставах муниципалитетов и иных сведений о трансформации системы, находящихся в открытом доступе. Поэтому мы считаем справедливым заключить, что на территории следующих регионов практика двоецентрия муниципальной власти имеет достаточно продолжительную историю. Муниципалитеты с двуглавой системой преимущественно расположены в республиках, в частности в Башкортостане, Кабардино-Балкарии, Марий Эл, Северной Осетии, Татарстане, Туве. В данную группу также можно включить Брянскую, Владимирскую, Пензенскую, Тульскую и Ульяновскую области.

\section{III. Переход от модели выборного главы к двуглавой модели}

В ряде случаев обращение к двуглавой модели стало промежуточным этапом на пути к обращению к одноглавой модели сити-менеджера. Однако в значительной части регионов после отмены прямых выборов сохраняется система управления муниципалитетами как главой муниципального образования, так и сити-менеджером. В группу таких субъектов на основе нашего анализа вошли Карачаево-Черкесия, Карелия (частично), Республика Коми (частично), Чеченская Республика, Чувашия, Хабаровский край, Амурская, Архангельская, Брянская, Владимирская, Вологодская, Курганская, Липецкая, Мурманская, Орловская, Пензенская, Ростовская, Рязанская, Тульская, Ульяновская области. Переход в регионах не происходил единовременно. В каждом регионе наблюдалась особая траектория формирования доминирующего принципа организации МСУ. 


\section{IV. Переход от модели выборного главы к одноглавой модели сити- менеджера}

В числе субъектов, в которых наблюдался непосредственный переход от модели выборного главы к системе единоличного правления сити-менеджером, можно обозначить следующие территории: республики Адыгея и Алтай, Краснодарский край, Свердловская, Челябинская, Оренбургская, Новосибирская, Омская, Новгородская, Томская, Сахалинская области.

\section{V. Переход от двуглавой модели к одноглавой модели сити-менеджера}

Как в случае территорий, где сохраняется двуглавая модель, в данной группе субъектов Федерации до 2010-х гг. также действовал принцип двоецентрия муниципальной власти. Переход к одноглавой модели впоследствии наблюдался нами в муниципалитетах в республиках Мордовия и Дагестан, а также в Саратовской и Смоленской областях.

\section{VI. Переход от выборной модели главы МСУ к двуглавой и затем к одноглавой модели сити-менеджера}

Ряд регионов за последние десятилетия переживал особенно частые изменения в организации муниципальной власти. В частности, в Алтайском и Красноярском краях, Нижегородской, Самарской, Свердловской, Тамбовской, Тверской областях и Ханты-Мансийском АО в муниципалитетах система выборного главы сменилась на двуглавую, а затем - на одноглавую. При этом на некоторых территориях, например в Самарской области, модели сменялись с разницей в 1-2 года (2014-2016 гг.), в то время как в других двуглавая система устанавливалась в 2010 г., а одноглавая постепенно принималась муниципалитетами между 2015 и 2018 гг.

В целом процесс преобразования системы МСУ в разных субъектах, независимо от группы, в которую они были нами включены, происходил вариативно, т. е. где-то модели МСУ менялись повсеместно и единовременно, а где-то хаотично распространялись на территории субъектов. Например, в Вологодской области в части муниципалитетов модель прямых выборов сменялась двуглавой моделью, в других сохраняется выборная модель, а в редких случаях закрепляется одноглавая модель. Кейс Камчатского края демонстрирует, что в регионе происходит активная смена моделей, но выборная модель может сменяться как одноглавой, так и двуглавой моделью. В Костромской области, напротив, в редких случаях происходит смена моделей, но наблюдается сохранение либо выборной модели, либо двуглавой. Практически идентичная ситуация в Курганской области: в данном субъекте не обнаружено доминирующей модели, распространенными являются и двуглавая модель, и модель выборного главы. В Ингушетии в ряде муниципалитетов сохранялась одноглавая модель, в другой части - двуглавая менялась на одноглавую. При этом для Ингушетии становится характерной именно одноглавая модель сити-менеджера.

В рамках нашего анализа было выявлено, что одноглавая модель сити-менеджера была принята в 938 из рассмотренных кейсов, двуглавая - в 918 кейсах, при 
этом в 280 случаях двуглавая модель являлась переходной, то есть в ряде муниципальных образований после нее была внедрена модель, при которой власть концентрируется в руках одного политического актора, то есть сити-менеджера.

Важным аспектом нашего наблюдения сменяемости моделей МСУ является определение интенсивности данного процесса (рис. 1).

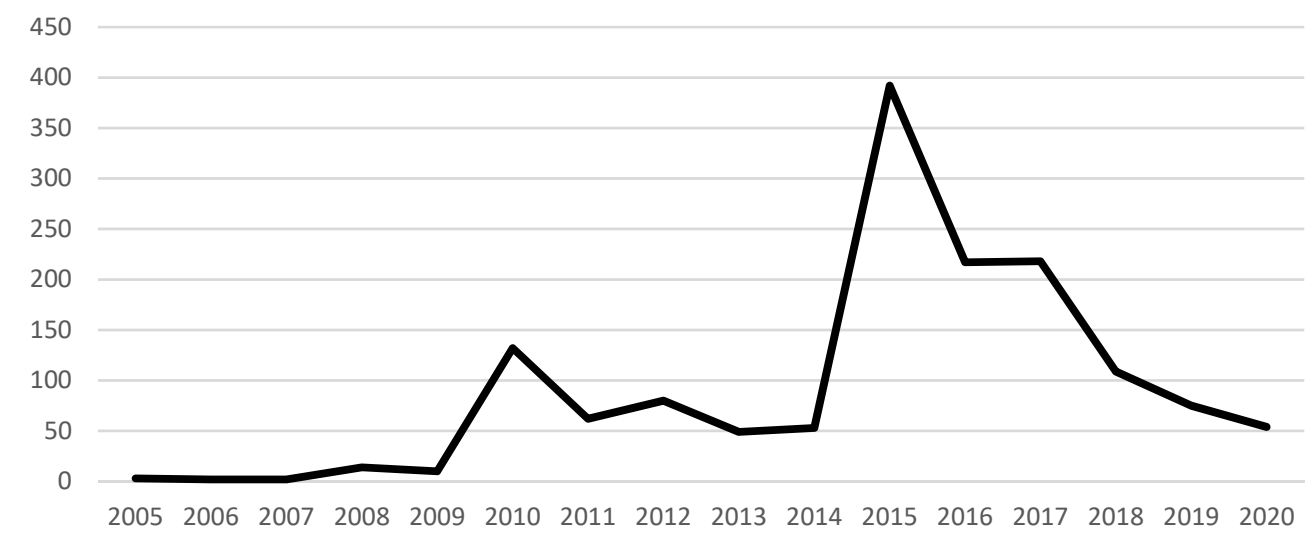

Рисунок 1. Интенсивность смены моделей МСУ, 2005-2020 гг.

Можно заметить, что пики интенсивности смены моделей приходятся на 2010 и 2015 гг. До 2010 г. включительно в основном наблюдается переход от выборной модели к двуглавой модели сити-менеджера. Яркими примерами являются Чувашия, Красноярский край и Нижегородская область. Массовый переход к одноглавой модели сити-менеджера начинается в 2015 г., после изменения многими муниципалитетами в 2014 г. своих уставов и накануне думских выборов 2016 г. В этот период как муниципалитеты, в которых прежде функционировала двуглавая модель, так и те, в которых глава определялся на прямых выборах, стали переходить на одноглавую модель управления.

В 2015 г. наиболее интенсивная смена моделей происходила в Дагестане, Красноярском крае, Оренбургской, Ростовской, Самарской, Смоленской, Челябинской областях. Напомним, что в Оренбургской и Челябинской областях осуществлялся переход от модели выборной непосредственно к одноглавой, а в Дагестане и Смоленской области - от двуглавой к одноглавой, в то время как в остальных упомянутых регионах до 2015 г. происходила отмена прямых выборов глав в пользу двуглавого управления мэром и сити-менеджером одновременно. Затем в 2016 г. одноглавая модель устанавливается в большинстве муниципалитетов Мордовии, Удмуртии, Саратовской области и Ханты-Мансийского АО. В 2017 г. муниципалитеты Алтайского края переходят с двуглавой модели на одноглавую, в Ярославской и Сахалинской областях отменяются прямые выборы глав и также устанавливается модель сити-менеджера. В Курганской области реформирование МСУ происходит преимущественно в 2019 г. В Нижегородской и Томской областях переход от двуглавой модели к одноглавой стал происходить недавно, стартовав в 2019 г. и продолжаясь в 2020 г. 
Стоит заметить, что в ряде регионов смена моделей происходила более интенсивно: в Орловской области и Ханты-Мансийском АО - в 2015-2016 гг., в Свердловской области и Забайкальском крае - в 2016-2017 гг., в Сахалинской области в 2017-2019 гг., в Томской и Нижегородской областях - в 2019-2020 гг. В других субъектах данный процесс происходил постепенно, растягиваясь на несколько лет: в Тамбовской области он протекал между 2015 и 2018 гг., в Краснодарском крае и Новгородской области - дольше на один год, между 2015 и 2019 гг., в Тверской области - с 2015 по 2020 гг., в Липецкой области - с 2016 по 2019 гг.

В рамках проверки влияния реформирования муниципальной системы в России на электоральную эффективность мы обратились к тестированию простой линейной регрессии, в которой в качестве отклика принимается доля голосов за В. Путина на президентских выборах 2018 г. (табл. 1). В выборку попали 88 наблюдений, преимущественно по региональным столицам и нескольким другим крупным городам (например, Нижний Тагил, Тольятти, Сургут и т. д.). В качестве ключевых независимых переменных использовались закодированные нами данные по моделям МСУ и факту их сменяемости. Так, модели выборного главы соответствовало значение категориальной переменной, равное 1 (при тестировании регрессионной модели категория является базовой, в табл. 1 представлена в виде константы), одноглавой модели сити-менеджера - 2, а двуглавой - 3. Для контролирования внешних эффектов нами принимались во внимание показатели, полученные в рамках проекта Агентства политических и экономических коммуникаций с его ежегодными рейтингами эффективности городского управления. Использовались оценки политической эффективности муниципальной власти, эффективности бюрократического аппарата и эффективности социально-экономической политики.

Тестирование модели продемонстрировало состоятельность утверждений о влиянии принципов организации МСУ на электоральные результаты действующей федеральной власти. В частности, коэффициенты при переменных дают основания говорить о том, что при выборной модели главы в среднем уровень поддержки В. Путина муниципалитетами составляет сравнительно невысокие 57 \%. В данном случае стоит принимать во внимание и специфику выборки, а именно рассмотрение преимущественно региональных центров, которые, как правило, характеризуются более протестным голосованием. Но и в этих условиях справедливым будет сказать, что установление в муниципалитете как одноглавой, так и двуглавой модели сити-менеджера способствует росту поддержки президента на 7,5-8 п.п. При этом переменная, фиксирующая факт сменяемости модели МСУ в период с 2005 по 2017 гг. включительно, имеет значение, но политическая турбулентность, вызванная сменой модели, приобретает негативные последствия для поддержки президента. Кроме того, на поддержку президента позитивно влияет политическая эффективность городской власти (что может казаться очевидным), но при этом эффективность городской бюрократии (рассчитываемая по другим критериям) оказывает отрицательное воздействие ${ }^{1}$.

\footnotetext{
${ }^{1}$ Показатели бюрократической эффективности в данном случае связаны главным образом с оптимизацией численности городской бюрократии и бюджетных расходов на нее, что, как видно, не способствовало росту электоральной поддержки федеральной власти. На самом деле это даже подкрепляет тезис о позитивном влиянии политической эффективности городской власти на поддержку президента страны: эта поддержка растет также в случае более мощного и обильно финансируемого бюрократического аппарата на местах.
} 
Результаты регрессионного анализа

\begin{tabular}{c}
\hline \hline Зависимая переменная: \\
\cline { 2 - 2 } \\
\hline
\end{tabular}

Одноглавая модель $7.987^{* * *}$

Двуглавая модель

Смена модели

Эффективность политики

Эффективность бюрократии

Эффективность соц.эконом. политики

Константа

\begin{tabular}{lc}
\hline Наблюдения & 88 \\
$\mathrm{R}^{2}$ & 0.309 \\
Adjusted $\mathrm{R}^{2}$ & 0.257 \\
Residual Std. Error & $6.742(\mathrm{df}=81)$ \\
F Statistic & $6.023^{* * *}(\mathrm{df}=6 ; 81)$ \\
\hline \hline Примечание: & ${ }^{*} \mathrm{p}<0.1 ;{ }^{* *} \mathrm{p}<0.05 ;{ }^{* * *} \mathrm{p}<0.01$
\end{tabular}

Таким образом, наше исследование показало, что инициированное центром в начале 2000-х гг. реформирование муниципальной системы управления, а также последовавший за этим в 2010-е гг. повторный пересмотр принципов организации управления на локальном уровне приносят свои плоды для политического режима в России. Кроме того, несмотря на формальное отделение местного самоуправления от государственной власти, процесс рекрутирования муниципальной элиты в России с этого времени тесным образом переплетен с формированием государственной бюрократии и депутатского корпуса.

С опорой на анализ биографий глав муниципалитетов в 80 изученных субъектах Федерации было установлено, что федеральный уровень власти активно использует муниципальный уровень в качестве кадрового резерва. Наиболее интенсивным с точки зрения частоты наблюдаемых случаев является обмен кадрами между муниципальными администрациями, местными и региональными парламентами. Одним из направлений карьерного развития политиков местного уровня является переход со службы в качестве главы муниципального района или городского 
округа в корпус депутатов. Но более важным политическим лифтом представляется переход муниципальных кадров в органы управления субъектами Федерации. Как показал наш анализ, подобная практика обозначилась в 2010 г. и продолжается до настоящего момента. Наблюдаются и обратные случаи, когда не только главы региональных столиц, но и руководители районных администраций приходят из регионального правительства. Кроме того, некоторые муниципальные руководители перемещаются в Федеральное правительство, а также становятся депутатами Госдумы или членами Совета Федерации. Примечательно, что циркуляция элит происходит в обоих направлениях, с муниципального на региональный и с регионального на муниципальный. Таким образом, происходит укрепление патрон-клиентских сетей в регионах, что консолидирует региональную управленческую систему, преодолевая прежние конфликты между губернаторами и мэрами.

Также исследование продемонстрировало целесообразность перехода к невыборным моделям определения муниципальных глав с точки зрения стабилизации политической системы. Регрессионный анализ является эмпирическим подтверждением того, что новая организация системы управления на локальном уровне способствует укреплению политического режима, что в значительной мере проявляется в поддержке действующего президента населением на выборах. При этом мы обнаружили, что как обращение к одноглавой модели сити-менеджера, так и установление двуглавой модели повышает электоральную эффективность существующего режима. Но при этом муниципальные реформы могут иметь и негативные эффекты, связанные с временным ростом политической турбулентности в период смены модели МСУ.

Итак, мы можем заключить, что в современной России региональная и муниципальная элита стали неотделимыми друг от друга, что соответствует особенностям функционирования региональных политических режимов в России, где не возникло двух самостоятельных уровней власти. Конвергенция региональной и муниципальной элиты в условиях муниципальной реформы, стартовавшей с принятием федерального закона об общих принципах организации местного самоуправления в 2003 г., взаимосвязана с выросшей потребностью в тесной кооперации региональной и муниципальной власти. Муниципальная элита является важным кадровым резервом для органов государственной власти. Даже при наличии политических издержек в виде потери автономии локального уровня можно говорить о том, что реформа способствовала формированию в России единой системы публичной власти, а фактическое сращивание региональной и муниципальной элиты имеет стабилизирующий политический эффект в регионах, играя важную роль в укреплении существующего политического режима.

\section{Ссылки / References}

1. Rodden J. A. Federalism // The Oxford handbook of political economy. Oxford and New York: Oxford University Press, 2006. P. 357-373.

2. Гельман В. Я. От местного самоуправления - к вертикали власти // Pro et contra. 2007. T. 11. №. 1. C. 6-18.

3. Reuter O. J. Local Elections in Authoritarian Regimes: An Elite-Based Theory with Evidence from Russian Mayoral Elections // Comparative Political Studies. 2016. № 49 (5). P. 662-697. 
4. Гельман В., Рыженков С. Локальные режимы, городское управление и «вертикаль власти» // Политическая экспертиза: ПОЛИТЭКС. 2010. № 4. С. 130-151.

5. Young J. F. Russia's elusive pursuit of balance in local government reform // Federalism and Local Politics in Russia. Cameron Ross und Adrian Campbell (eds.). London and New York: Routledge, 2009. P. 248-262.

6. Faure-Grimaud A., Laffont J. J., Martimort D. Risk averse supervisors and the efficiency of collusion // Contributions to Theoretical Economics. 2002. Vol. 2. № 1. Available at: London: LSE Research Online http://eprints.lse.ac.uk/20/2/A_Faure-Grimaud.pdf

7. Туровский Р. Ф. Местное самоуправление в России как агент в принципал-агентских отношениях с государственной властью // Социально-экономические явления и процессы. 2013. № 12 (058). С. 159-167.

8. Туровский Р. Ф. Местное самоуправление в России и эволюция политического режима // Pro nunc. Современные политические процессы. 2015. № 1 (14). С. 82-98.

9. Лапин В. А., Челпан П. И. Самоокупаемая реформа? На пути к устойчивому развитию // Полития. 2003. № 4. С. 91-108.

10. 10. Campbell A. Vertical or triangle? Local, regional and federal government in the Russian Federation after Law 131 // Federalism and Local Politics in Russia. Cameron Ross und Adrian Campbell (eds.). London and New York: Routledge, 2008. P. 279-299.

11. Wollmann H., Gritsenko E. Local Self-Government in Russia-between de-centralisation and recentralisation // Federalism and local politics in Russia. Cameron Ross und Adrian Campbell (eds.). London and New York, 2009. P. 227-248.

12. Трудолюбов А. С., Экба М. А. Опыт реформирования административнотерриториального деления на поселенческом уровне в современной России // Южнороссийский журнал социальных наук. 2018. № 3. С. 177-196.

13. Трудолюбов А. С. Эволюция моделей местного самоуправления на поселенческом уровне в современной России // Политическая наука. 2019. № 2.С. 95-123. 